\title{
撉寺 䠌满
}

日本鉄鎆協会会長

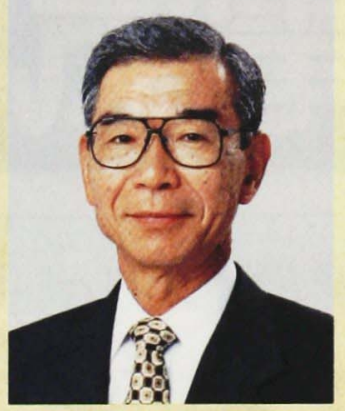

鉄を当用漢字ではこの字を使います。金を失うと読めま す。元々の旧漢字では鐵という字を使っていました。金に 王なる哉と書いてあります。この事は一見矛盾するように 感じられますが, 実は, 同じ事の両面であるとも考えられ ます。鉄はたくさん産出して安い, 安いから他の金属にも ましてたくさん使われる。現に，現在地球上で使われてい る金属材料の $90 \%$ 以上は鉄であります。

この事は，大袈裟に言えば宇宙の捸理に基づくのです。 最近の天文学では， 150 億年に亘る宇宙の歴史や，星の一 生, 46 億年の太陽系, 地球の歴史もある程度わかってき ました。恒星の一生の輪迴の中で，核融合反応や，核分裂 反応が起こりますが,これらは結局，もつとも原子核の安 定性の高い鉄までいつて止まると考えられています。悠久 の時間の後には宇宙は鉄だらけになるのかもしれません。

宇宙の塵が集まって出来た地球は中心部の核まで含める と 33\%ぐらいが鉄です。地表の地層だけとつても，酸素 $46 \%$ ，珪素 $27.7 \%$ ，アルミニウム $8.13 \%$ について $5 \%$ を 占めています。金属の中では三番手ですが，地球上に生物 が発生し炭酸同化作用によって酸素が発生したときに生じ た純度の高い酸化鉄, 水酸化鉄の沈殿鉱床が䌂まつて大量 に賦存するということ，化学的な反応性の関係から炭素 （炭）があれば大気中で容易に還元して単体金属が得られ るということが重なって，有史以来人類の文明は鉄ととも に発展してきたわけであります。

鉄はまた，本来特異な物性があります。その最たるもの は強磁性体であるということです。この性質をもつとも典 型的に使っているのが, 発電機, 変圧器, 電動機を中心と する電気機械であります。そのほか，体心立方という独特 の結晶格子構造によって, 化学成分と熱処理の選択で多様 な機械的性質を実現出来るという特質があります。たつた 一つ具合の悪い性質は錆びてゆくということですが, これ もメッキ等の防錆技術によって実用的には解決済みと考え てよいでしょう。

鉄の製造自体は大規模な設備装備を前提とした典型的な 大量生産方式です。日本鉄鋼業は戦後 70 年代にかけて急 速な伸長を遂げました。そのころまでに世界で初めて, 日
本で実現された大規模海浜製鉄所一大型高炉一純酸素転炉 一連続鋳造一連続圧延の組み合わせという現代製鉄業のコ ンセプトは，現在にいたるまで世界の標準となっています。 現在世界一の生産量, 能率を誇る製鉄所は韓国の POSCO 光陽製鉄所ですが, 80 年代から 90 年代にかけて完成した この製鉄所もこのコンセプトを忠実に実現したものです。

基本技術の変化改革著しい, 電気, 電子, 情報産業と比 べると，30 年以上にわたってコンセプトの変わらない産 業であるということは, 一面, 問題であるとの見方も出来 ます。しかし，製鉄所一つに 2 兆円に近い投資を必要とす る製鉄業にとっては，先行馬のメリットもなしとしないの も現実でしょう

では, 技術としての課題は何か, 何をねらつて開発をし ているのか？一口で言えば,より高い生産性, より高い 品質の飽くなき追求ということに尽きます。

材料として多様な性質を実現できる鉄を使って，社会， 需要産業のニーズに即応した, 新しい材料への間断なき挑 戦がその一です。日本のあらゆる需要産業は, 間違いなく 世界一の材料を使えるという立場にあります。

さらに，鉄という素材は根源的に安価でなくては生きて いけない素材であります。国際市場ではドル表示の価格だ けが競争力のスケールです。高騰やむことない円/ドルレ 一トの中で私共は正直なところ苦戦を強いられています。 しかし、これも日本の工業が自分でもたらした経済上の結 果であります。競争力は自分でつけるしかありません。そ のためには, 生産性の向上によるコストダウン以外に王道 はありえません。これがその二です。

具体的には,これらを実現するために, Computer, 高 速 digital 制御装置, 高性能 AC Motorなど, 電気, 電 子, 情報に係わる技術の進展はいち早く導入実機化し, 製 品々質，生産性の向上を実現してきました。

今後も, 電気産業界にはより高性能の材料供給を続ける とともに，自身の生産性向上のために電気産業界の提供す る新技術の積極的な採用を試み，密接な関係が続くものと 考えています。

21 世紀も鉄鋼の世紀です。 